\title{
Radiotherapy-induced nausea and vomiting (RINV): MASCC/ESMO guideline for antiemetics in radiotherapy: update 2009
}

\author{
Petra Christine Feyer • Ernesto Maranzano • \\ Alexander Molassiotis • Fausto Roila • \\ Rebecca A. Clark-Snow • Karin Jordan
}

Received: 29 March 2010/Accepted: 1 July 2010 / Published online: 10 August 2010

(C) Springer-Verlag 2010

\begin{abstract}
Radiation-induced nausea and vomiting (RINV) are still often underestimated by radiation oncologists. However, as many as $50-80 \%$ of patients undergoing radiotherapy (RT) will experience nausea and/or vomiting, depending on the site of irradiation. Fractionated RT may involve up to 40 fractions over a 6-8-week period, and prolonged symptoms of nausea and vomiting affect quality of life. Furthermore, uncontrolled nausea and vomiting may result in patients delaying or refusing further radiotherapy. Incidence and severity of nausea and vomiting depend on RT-related factors (irradiated site, single and total dose, fractionation, irradiated volume, radiotherapy techniques) and patient-related factors (gender, general health of the patient, age, concurrent or recent chemotherapy, psychological state, tumor stage). The new proposed guideline from the Multinational Association of Supportive Care in
\end{abstract}

Perugia Antiemetic Consensus Conference 2009

P. C. Feyer $(\square)$

Department of Radiotherapy, Nuclear Medicine,

Vivantes Medical Center Berlin-Neukölln,

Rudower Str. 48,

12351 Berlin, Germany

e-mail: petra.feyer@vivantes.de

E. Maranzano

Department of Oncology and Radiation Oncology Centre,

Azienda Ospedaliera "S. Maria",

U.O. de Radioterapia Oncologica,

Via T. di Joannuccio 1,

05100 Terni, Italy

\section{A. Molassiotis}

School of Nursing, Midwifery and Social Work,

University of Manchester,

Manchester M13 9PL, UK
Cancer and European Society of Clinical Oncology summarises the updated data from the literature and takes into consideration the existing guidelines. According to the irradiated area (the most frequently studied risk factor), the proposed guideline divided these areas into four levels of emetogenic risk: high, moderate, low and minimal. In fact, the emetogenicity of radiotherapy regimens and recommendations for the appropriate use of antiemetics including 5-hydroxytryptamine receptor antagonists and steroids are given in regard to the applied radiotherapy or radiochemotherapy regimen. This updated guideline offers guidance to the treating physicians for effective antiemetic therapies in RINV.

Keywords Radiotherapy-induced nausea and vomiting . Risk factors $\cdot 5-\mathrm{HT}_{3}$ receptor antagonists $\cdot$ Guidelines

\section{F. Roila}

Department of Oncology and Medical Oncology Division

Azienda Centre Ospedaliera "S. Maria",

Via T. di Joannuccio 1,

05100 Terni, Italy

\section{R. A. Clark-Snow}

The University of Kansas Cancer Center,

3901 Rainbow Boulevard,

Kansas, KS 66160-7820, USA

\section{K. Jordan}

Department of Medical Oncology and Hematology,

University of Halle,

Ernst Grube Strasse 40,

Halle, Germany 


\section{Introduction}

Past observational studies on radiotherapy-induced nausea and vomiting (RINV) highlight that the overall cumulative incidence of vomiting and nausea is about $50-80 \%$ of patients undergoing radiotherapy $[10,11,29]$. It was also highlighted that the attitude of radiation oncologists in prescribing antiemetic drugs as a rescue, with a large range of doses and schedules, and that 5hydroxytryptamine $\left(5-\mathrm{HT}_{3}\right)$ receptor antagonists rather than other antiemetics were generally being used [42, 7 , 9, 14, 29]. In 2009, undertreatment of RINV of patients undergoing radiotherapy is still a reality, as shown in two large observational trials [5, 29].

Patients submitted to total body irradiation (TBI), half body irradiation (HBI) or abdominal radiotherapy are at a major risk of nausea and vomiting. Poorly controlled nausea and vomiting can result in potentially lifethreatening medical conditions, including dehydration and electrolyte imbalance. Some patients find nausea and vomiting so distressing that they are willing to compromise their treatment regimens to avoid these symptoms. As such, this may have serious consequences for treatment success. Studies have revealed an increased risk of treatment failure and poor tumour control, when for example, the overall radiotherapy time is increased. Few randomized controlled clinical trials have evaluated the efficacy of various antiemetic drugs in preventing RINV. Since the last update in 2005 [7, 9], only one welldesigned double-blind randomized study in patients undergoing upper abdominal radiation treated with a $5 \mathrm{HT}_{3}$ receptor antagonist in combination with shortcourse dexamethasone versus a $5-\mathrm{HT}_{3}$ receptor antagonist alone was published [46].

The purpose of this updated MASCC/ESMO guideline is to provide a consensus statement derived from published articles as well as expert opinion about antiemetic therapy for radiotherapy-induced nausea and vomiting. This specific recommendation does not include a guideline on radiotherapy-induced nausea and vomiting in children.

\section{Literature search strategy}

A Medline search from January 2004 to June 2009 was conducted for English language articles using the search terms: "radiotherapy-induced emesis" and radiotherapyinduced nausea". Abstracts were reviewed, and articles were excluded if they possessed any of the following characteristics: review articles, cause for emesis other than radiotherapy or radiochemotherapy.

\section{Current practice guidelines for RINV}

Current Multinational Association of Supportive Care in Cancer (MASCC), American Society of Clinical Oncology (ASCO) and National Cancer Comprehensive Network (NCCN) practice guidelines for the use of antiemetics in radiotherapy are in detail different when classifying radiation emetogenic risk categories and the indications for the use of antiemetic drugs [7, 9, 22, 33, 45]. This diversity of recommendations reflects the limited amount of high-level evidence available to date (i.e. few randomized controlled trials and the small number of patients entered in each trial).

\section{Observational trials}

The incidence and management of RINV have been recently updated in two prospective observational studies [5, 29]. The first survey showed that although approximately one third of radiotherapy patients experienced nausea and vomiting, the vast majority (85\%) were not prescribed antiemetics [5].

In the latest observational study by the Italian Group for Antiemetic Research in Radiotherapy (IGARR), 1,020 patients receiving different kinds of radiotherapy were included [29]. Overall vomiting and/or nausea was reported by $280(27.9 \%)$ of the patients. The median time to the first episode of vomiting was 3 days. Antiemetic drugs were administered to 170 patients $(17 \%)$ of the 1,004 evaluable patients; whereas $12.4 \%$ received prophylactic antiemetic treatment and $4.6 \%$ rescue treatment. These results are in accordance with the previous study (IGARR) and reinforce that the tendency of radiation oncologists is not to prescribe antiemetics. Additionally, in the previous study, only a minority (14\%) of patients received an antiemetic drug, and the prescriptions were more often symptomatic rather than prophylactic ( $9 \%$ and 5\%, respectively) [42].

A European survey on 200 radiation oncologists from France, Italy, Germany, Spain and the UK suggested that $5-\mathrm{HT}_{3}$ receptor antagonists are underused in patients receiving radiotherapy. Only $52 \%$ of patients who received highly or moderately emetogenic radiotherapy actually received a $5-\mathrm{HT}_{3}$ receptor antagonist. There are also differences in the prescribing procedure among the evaluated countries [8]. A 5- $\mathrm{HT}_{3}$ receptor antagonist was more frequently prescribed if the patient received radiation with chemotherapy than in radiotherapy alone (46\% versus $33 \%$ ).

\section{Risk classification}

One of the main stumbling blocks to effective treatment has been a lack of consensus on the potential for emesis 
with different radiotherapy techniques and doses. The updated review of the literature reveals only two suitable new references, derived from two large prospective observational studies $[5,29]$. In the second IGARR study by Maranzano et al., a higher incidence for vomiting than would be expected from the current risk classification for patients receiving head and neck and brain radiation was observed. In the study by Enblom et al., the results were similar; however, nausea was defined as one of the major endpoints. Due to the results from these two studies, a reclassification of head and neck and brain radiation to the low emetogenic (last consensus: minimal risk) risk group is necessary. The risk classification is depicted in Table 3. In the second IGARR study, a multifactorial analysis evaluated the significant risk factors for RINV [29]. Concomitant radiochemotherapy, previous experience of vomiting induced by chemotherapy, irradiated site (upper abdomen) and field size (> $400 \mathrm{~cm}^{2}$ ) were significantly correlated with a higher incidence of RINV.

\section{Antiemetics-randomized clinical trials}

Few small randomized clinical trials have evaluated the efficacy of various antiemetic drugs in preventing RINV. Generally, patients entering these trials are those submitted to TBI, HBI or upper-abdomen irradiation because of the higher risk of developing nausea and/or vomiting.

\section{Prophylaxis with non-5-HT $\mathrm{H}_{3}$ receptor antagonists}

Three randomized trials on RINV in patients treated with fractionated radiotherapy to the abdomen and thorax were published before the introduction of $5-\mathrm{HT}_{3}$ receptor antagonists. In the first study, 39 patients were randomized to receive oral metoclopramide or nabilone. In the second, 89 patients were treated with oral metoclopramide, prochlorperazine or placebo, and in the third, 11 patients received tetrahydrocannabinol or prochlorperazine $[7,9$, $35,44]$. Only one randomized study has been carried out with 43 patients submitted to single-fraction palliative radiotherapy to the thoracic and/or lumbar spine. In this study, chlorpromazine was compared with two different doses of levonantradol [25].

All of these studies enrolled a small number of patients (median 46) and showed no difference among the various compounds determining a limited antiemetic efficacy (complete protection of vomiting in only about $50 \%$ of cases).

\section{Prophylaxis with $5-\mathrm{HT}_{3}$ receptor antagonists}

In the last decade, the 5- $\mathrm{HT}_{3}$ receptor antagonists have been used more extensively in clinical practice to treat RINV [7, 9]. Tables 1 and 2 show randomized trials with $5-\mathrm{HT}_{3}$ receptor antagonists and/or corticosteroids in patients submitted to radiotherapy with single or fractionated regimens. Different compounds and a wide range of doses and schedules have been used. One interesting trial evaluated the efficacy of an escalating dose of oral ondansetron (OND) in the prevention of emesis induced by fractionated radiotherapy. The dose-adapted regimen of OND was effective and showed the possibility to reduce costs without compromising the activity [26]. Antiemetics were generally started $1-2 \mathrm{~h}$ before radiotherapy and usually continued until the end of irradiation when a fractionated regimen of dose was adopted. The oral route was predominant $(70 \%)$.

The seven published trials mostly with ondansetron regarding patients submitted to upper-abdomen irradiation showed that $5-\mathrm{HT}_{3}$ receptor antagonists achieved significantly greater protection for RINV than metoclopramide, phenothiazines or placebo (Table 1; [1, 3, 12, 23, 36, 37]). Also, in patients treated with TBI or HBI, $5-\mathrm{HT}_{3}$ receptor antagonists provided as expected, significantly better protection for RINV than placebo or conventional antiemetics (Table 2; [34, 39-41, 43].

Furthermore, Spitzer [40] showed in his randomized trial that granisetron (GRAN) and OND are equally effective in controlling emesis during TBI. One further trial confirmed that a $5-\mathrm{HT}_{3}$ receptor antagonist (GRAN) achieved a significantly better protection against RINV than placebo in patients undergoing fractionated upperabdomen irradiation [23]. This trial compared $1 \mathrm{mg}$ of oral GRAN bid versus $2 \mathrm{mg}$ GRAN once a day in patients submitted to fractionated radiotherapy to abdomino-pelvic area and showed no significant differences between the two modalities in controlling RINV. Further reports support the efficacy of $5-\mathrm{HT}_{3}$ receptor antagonists in this setting $[19,21]$.

The most commonly used $5-\mathrm{HT}_{3}$ receptor antagonists are ondansetron and granisetron. Side effects were evaluated and compared by Goodin [13]. The adverse effects of $5-\mathrm{HT}_{3}$ receptor antagonists are generally mild, with headache, constipation, diarrhea and asthenia mainly described [18, 34, 37, 40]. Sometimes, rather than causing constipation, 5- $\mathrm{HT}_{3}$ receptor antagonists reduced the frequency of diarrhea, a troublesome side effect due to acute radiation enteric toxicity [10-12].

The relatively new $5-\mathrm{HT}_{3}$ receptor antagonist palonosetron and transdermal granisetron patch might be interesting options especially for patients receiving radiotherapy. To 
Table 1 Randomized clinical trials with 5- $\mathrm{HT}_{3}$ receptor antagonists and/or steroids in patients submitted to upper abdomen irradiation

\begin{tabular}{|c|c|c|c|c|}
\hline $\begin{array}{l}\text { Author } \\
\text { (reference), } \\
\text { ( } N \text { patients) }\end{array}$ & Radiotherapy regimen & $\begin{array}{l}\text { Antiemetic } r \\
\text { andomization }\end{array}$ & $\begin{array}{l}\text { Percent of complete } \\
\text { response }\end{array}$ & Results \\
\hline [36], $N=82$ & $8-10$ Gy single fraction & $\begin{array}{l}\text { OND } 8 \mathrm{mg} \times 3 / \text { day p.o. } \\
\text { for } 5 \text { days } \\
\text { MCP } 10 \mathrm{mg} \times 3 / \text { day p.o. } \\
\text { for } 5 \text { days }\end{array}$ & $\begin{array}{l}97 \% \\
46 \%\end{array}$ & $\begin{array}{l}\text { OND better than } \\
\text { MCP }\end{array}$ \\
\hline$[37], N=135$ & $\begin{array}{l}1.8 \mathrm{~Gy} / \mathrm{day} \text { for at least } \\
5 \text { fractions }\end{array}$ & 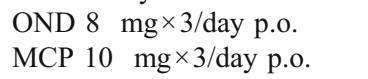 & $\begin{array}{l}61 \% \\
35 \%\end{array}$ & $\begin{array}{l}\text { OND better than } \\
\text { MCP (for vomiting) }\end{array}$ \\
\hline$[3], N=50$ & At least 6 Gy single fraction & $\begin{array}{l}\text { DOL } 0.3 \mathrm{mg} / \mathrm{kg} \text { i.v. } \\
\text { DOL } 0.6 \mathrm{mg} / \mathrm{kg} \text { i.v. } \\
\text { DOL } 1.2 \mathrm{mg} / \mathrm{kg} \text { i.v. } \\
\text { Placebo }\end{array}$ & $\begin{array}{l}100 \%^{\mathrm{a}} \\
93 \%^{\mathrm{a}} \\
83 \%^{\mathrm{a}} \\
54 \%^{\mathrm{a}}\end{array}$ & $\begin{array}{l}\text { DOL better than } \\
\text { placebo }\end{array}$ \\
\hline$[12], N=111$ & $\begin{array}{l}\text { At least } 1.7 \text { Gy/day for } \geq 10 \\
\text { fractions }\end{array}$ & $\begin{array}{l}\text { OND } 8 \mathrm{mg} \times 2 / \text { day p.o. } \\
\text { Placebo }\end{array}$ & $\begin{array}{l}67 \% \\
45 \%\end{array}$ & $\begin{array}{l}\text { OND better than } \\
\text { placebo }\end{array}$ \\
\hline [1], $N=23$ & $\begin{array}{l}2 \text { Gy/day to } 30 \text { Gy in } \\
15 \text { fractions }\end{array}$ & $\begin{array}{l}\text { TRO } 5 \mathrm{mg} / \text { day p.o. } \\
\text { MTC } 10 \mathrm{mg} \times 3 / \text { day p.o. }\end{array}$ & $\begin{array}{l}91 \% \\
50 \%\end{array}$ & TRO better than MTC \\
\hline [23], $N=260$ & $\begin{array}{l}10-30 \text { fractions } \\
\text { (1.8-3 Gy/fraction) }\end{array}$ & $\begin{array}{l}\text { GRAN } 2 \text { mg/day } \\
\text { Placebo }\end{array}$ & $\begin{array}{l}57.5 \% \\
42 \%\end{array}$ & $\begin{array}{l}\text { GRAN better than } \\
\text { placebo }\end{array}$ \\
\hline$[20] N=154$ & $\begin{array}{l}\text { At least } 5 \text { fractions to } \\
\text { minimum total dose } \\
\text { of } 20 \text { Gy }\end{array}$ & $\begin{array}{l}\text { DEX } 2 \mathrm{mg} \times 3 / \text { day p.o. } \\
\text { for } 5-7 \text { days } \\
\text { Placebo }\end{array}$ & $\begin{array}{l}70 \% \\
49 \%\end{array}$ & $\begin{array}{l}\text { DEX better than } \\
\text { placebo }\end{array}$ \\
\hline$[46], N=211$ & $\begin{array}{l}\geq 15 \text { fractions to the upper } \\
\text { abdomen to a dose of } \\
20 \text { or more Gy }\end{array}$ & $\begin{array}{l}\text { OND } 8 \mathrm{mg} \text { bid for } 5 \\
\text { days + placebo for } 5 \text { days } \\
\text { OND } 8 \mathrm{mg} \text { bid+DEX } \\
4 \mathrm{mg} \text { for } 5 \text { days }\end{array}$ & $\begin{array}{l}71 \%^{\mathrm{b}} \\
12 \%^{\mathrm{c}} \\
78 \%^{\mathrm{b}} \\
23 \%^{\mathrm{c}}\end{array}$ & $\begin{array}{l}\text { OND + DEX better } \\
\text { than OND alone }\end{array}$ \\
\hline [32], $N=288$ & $\begin{array}{l}\text { Fractionated radiotherapy } \\
\text { of moderate or high } \\
\text { emetogenic potential }\end{array}$ & $\begin{array}{l}5 \text { mg TRO daily starting } \\
1 \text { day before radiotherapy } \\
\text { until } 7 \text { days after end } \\
\text { of radiotherapy } \\
5 \text { mg TRO on an as } \\
\text { needed base }\end{array}$ & $\begin{array}{l}\text { Incidence of vomiting } \\
\text { was } 2.19(p=0.001) \text { times } \\
\text { higher in the rescue } \\
\text { TRO arm }\end{array}$ & $\begin{array}{l}\text { Prophylactic TRO } \\
\text { better than rescue } \\
\text { TRO }\end{array}$ \\
\hline
\end{tabular}

OND ondansetron, $M C P$ metoclopramide, $D O L$ dolasetron, $P C P$ prochlorperazine, TRO tropisetron, DEX dexamethasone, p.o. orally, i.v. intravenously

${ }^{\mathrm{a}}$ Complete plus major response

${ }^{\mathrm{b}}$ Primary endpoint, CR day $1-5$

${ }^{\mathrm{c}}$ Secondary endpoint, $\mathrm{CR}$ day $1-15$

date, only a few abstracts are available on the use of palonosetron and the transdemal granisetron patch in RINV showing promising activity $[2,4]$. Therefore, no specific recommendation for these $5-\mathrm{HT}_{3}$ receptor antagonists is currently possible. Further research evaluating the potential role of palonosetron and the transdermal granisetron patch is warranted.

\section{Prophylaxis with a 5-HT 3 receptor antagonist + dexamethasone}

The effect of adding a short course of low-dose dexamethasone (days 1-5) to a $5-\mathrm{HT}_{3}$ receptor antagonist was assessed in a National Cancer Institute of Canada (NCIC) trial, in which 211 patients receiving RT to the upper abdomen as shown in Table 1 [46]. Patients were randomly assigned to ondansetron (8 $\mathrm{mg}$ twice a day) plus either dexamethasone (4 $\mathrm{mg}$ daily) or placebo with the first five treatment fractions. Patients with persistent nausea and/or vomiting received ondansetron plus prochlorperazine with subsequent RT treatments as a rescue option. During the first 5 days, there was a non-significant trend toward improved complete control of nausea (50\% versus 38\% with placebo) and vomiting (78\% versus $71 \%$ ) (primary end point not reached). However, the effects of dexamethasone extended beyond the initial period, significantly more patients had complete control of emesis over the entire 
Table 2 Randomized clinical trials with 5- $\mathrm{HT}_{3}$ receptor antagonists in patients submitted to total body irradiation (TBI) and half body irradiation (HBI)

\begin{tabular}{|c|c|c|c|c|}
\hline $\begin{array}{l}\text { Author (reference) } \\
\text { ( } N \text { patients) }\end{array}$ & Radiotherapy regimen & $\begin{array}{l}\text { Antiemetic } \\
\text { randomization }\end{array}$ & $\begin{array}{l}\text { Percent of complete } \\
\text { response }\end{array}$ & Results \\
\hline$[43], N=20$ & $\begin{array}{l}10.5 \text { Gy } \\
\text { TBI single fraction }\end{array}$ & $\begin{array}{l}\text { OND } 8 \text { mg i.v. } \\
\text { Placebo }\end{array}$ & $\begin{array}{l}90 \%{ }^{\mathrm{a}} \\
50 \%{ }^{\mathrm{a}}\end{array}$ & $\begin{array}{l}\text { OND better than } \\
\text { placebo }\end{array}$ \\
\hline [39], $N=20$ & $\begin{array}{l}1.2 \mathrm{~Gy} \times 3 / \text { day } \\
\text { TBI } 11 \text { fractions to a total } \\
\text { dose of } 13.2 \mathrm{~Gy}\end{array}$ & $\begin{array}{l}\text { OND } 8 \mathrm{mg} \times 3 / \text { day p.o. } \\
\text { Placebo }\end{array}$ & $\begin{array}{r}50 \% \\
0 \%\end{array}$ & $\begin{array}{l}\text { OND better than } \\
\text { placebo }\end{array}$ \\
\hline$[34], N=30$ & $\begin{array}{l}7.5 \text { Gy } \\
\text { TBI single fraction }\end{array}$ & $\begin{array}{l}\text { GRAN } 3 \text { mg i.v. versus } \\
\text { MTC } 20 \mathrm{mg} \text { i.v. plus } \\
\text { DEX } 6 \quad \mathrm{mg} / \mathrm{m}^{2} \text { i.v. plus } \\
\text { LOR } 2 \mathrm{mg} \text { i.v. }\end{array}$ & $\begin{array}{l}53 \% \\
13 \%\end{array}$ & $\begin{array}{l}\text { GRAN better than } \\
\text { MTC + DEX + LOR }\end{array}$ \\
\hline$[15], N=116$ & 7-7.7 Gy & OND 8 mg (i.v.?) plus & $84 \%$ & $\begin{array}{l}\text { OND }+ \text { DEX better than } \\
\text { paspertin }+ \text { DEX }\end{array}$ \\
\hline [41], $N=66$ & $\begin{array}{l}8-12.5 \text { Gy } \\
\text { HBI single fraction }\end{array}$ & $\begin{array}{l}\text { OND } 8 \text { mg } \times 2 \text { p.o. versus } \\
\text { CLP } 25 \mathrm{mg} \times 3 \text { p.o. plus } \\
\text { DEX } 6 \text { mg } \times 3 \text { p.o. }\end{array}$ & $\begin{array}{l}94 \% \\
34 \%\end{array}$ & $\begin{array}{l}\text { OND better than } \\
\text { CLP+DEX }\end{array}$ \\
\hline$[40], N=34$ & $\begin{array}{l}1.2 \mathrm{~Gy} \times 3 / \text { day } \\
\text { TBI } 11 \text { fractions to a total } \\
\text { dose of } 13.2 \text { Gy }\end{array}$ & $\begin{array}{l}\text { OND } 8 \quad \mathrm{mg} \times 3 / \text { day p.o. versus } \\
\text { GRAN } 2 \quad \mathrm{mg} \times 1 / \text { day p.o. }\end{array}$ & $\begin{array}{l}47 \% \\
61 \%\end{array}$ & No difference \\
\hline
\end{tabular}

OND ondansetron, GRAN granisetron, MTC metoclopramide, LOR lorazepam, CLP chlorpromazine, DEX dexamethasone, p.o. orally, i.v. intravenously

${ }^{a}$ All patients received intravenous dexamethasone $(8 \mathrm{mg})$ and phenobarbitone $\left(60 \mathrm{mg} / \mathrm{m}^{2}\right)$

course of RT (23\% versus $12 \%$, with placebo) (secondary end point was reached). Although this study did not demonstrate a statistically significant benefit for the primary end point, results on several secondary end points, as well as quality of life data, strongly suggest that benefits do exist with the addition of dexamethasone, and therefore, dexamethasone is now recommended in combination with a $5-\mathrm{HT}_{3}$ receptor antagonist as an option for patients in the moderate emetogenic risk category (Table 3).

\section{Prophylaxis with corticosteroids}

Their widespread availability, low cost and benefit make corticosteroids to be a very interesting antiemetic drug. Regarding the use of dexamethasone (DEX) as a single agent for the prophylaxis of RINV, a double-blind study has been published so far [20]. Patients who underwent fractionated radiotherapy to the upper abdomen received either oral DEX ( $2 \mathrm{mg} \times 3 /$ day $)$ or placebo only in the first week of radiotherapy, even though the courses lasted up to 6 weeks (Table 1). Complete protection from RINV was significantly better in the DEX group with acceptable side effects. However, no overall positive effect on global quality of life could be detected. Considering that the majority of emetic episodes occurred early in the treatment course, it is indeed arguable that prophylactic antiemetics may not be necessary for a full course of radiotherapy, and therefore, a treatment for the first week might be sufficient [7, 9, 20, 22]. More studies evaluating the efficacy of steroids in comparison to $5-\mathrm{HT}_{3}$ receptor antagonists and as a combination regimen are further warranted to enlarge the body of evidence.

\section{Prophylaxis with neurokinin-1 receptor antagonists}

Extensive clinical trials have established an important role for the neurokinin-1 (NK-1) receptor antagonists in the management of chemotherapy-induced nausea and vomiting (CINV) [18]. So far, neither aprepitant nor casopitant have been formally tested for patients with radiation-induced nausea and vomiting in a randomized trial and can therefore not be recommended, although the pathogenesis of RINV is thought to be mediated in parts by substance $\mathrm{P}[47]$.

\section{Duration of prophylaxis}

The appropriate duration of $5-\mathrm{HT}_{3}$ receptor antagonist prophylaxis for patients receiving fractionated radiotherapy is not clear. Although randomized trials have used $5-\mathrm{HT}_{3}$ receptor antagonists either for extended periods [12, 36, 46] 
Table 3 Radiotherapy-induced emesis: radiation emetic risk levels and new MASCC and ESMO guidelines

\begin{tabular}{|c|c|c|c|c|}
\hline $\begin{array}{l}\text { Risk } \\
\text { level }\end{array}$ & Risk factors & $\begin{array}{l}\text { Antiemetic } \\
\text { guidelines }\end{array}$ & $\begin{array}{l}\text { MASCC evidence (level } \\
\text { of scientific confidence/ } \\
\text { level of consensus) }\end{array}$ & $\begin{array}{l}\text { ESMO evidence (type } \\
\text { of evidence/grade of } \\
\text { recommendation) }\end{array}$ \\
\hline High & TBI & $\begin{array}{l}\text { Prophylaxis with } 5-\mathrm{HT}_{3}- \\
\text { RA+DEX }\end{array}$ & $\begin{array}{l}\text { High/high (for the addition } \\
\text { of DEX: moderate/high) }\end{array}$ & $\begin{array}{l}\text { II/B (for the addition } \\
\text { of DEX: IIIC) }\end{array}$ \\
\hline Moderate & Upper abdomen, HBI, UBI & $\begin{array}{l}\text { Prophylaxis with } 5-\mathrm{HT}_{3}- \\
\text { RA+optional DEX }\end{array}$ & $\begin{array}{l}\text { High/high (for the addition } \\
\text { of DEX: moderate/high) }\end{array}$ & $\begin{array}{l}\text { II/A (for the addition } \\
\text { of DEX: IIB) }\end{array}$ \\
\hline Low & $\begin{array}{l}\text { Cranium (all), craniospinal, } \\
\text { H \& N, lower thorax region, pelvis }\end{array}$ & $\begin{array}{l}\text { Prophylaxis or rescue } \\
\text { with } 5-\mathrm{HT}_{3}-\mathrm{RA}\end{array}$ & $\begin{array}{l}\text { Moderate/high for rescue: } \\
\text { low/high }\end{array}$ & III/B for rescue: IV/C \\
\hline Minimal & Extremities, breast & $\begin{array}{l}\text { Rescue with dopamine receptor } \\
\text { antagonist or } 5-\mathrm{HT}_{3}-\mathrm{RA}\end{array}$ & Low/high & $\mathrm{IV} / \mathrm{D}$ \\
\hline
\end{tabular}

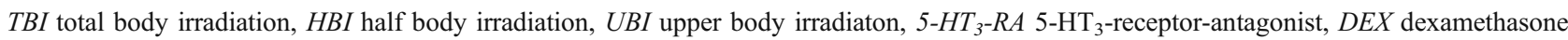
In concomitant radiochemotherapy, the antiemetic prophylaxis is according to the chemotherapy-related antiemetic guidelines of the corresponding risk category, unless the risk of emesis is higher with radiotherapy than chemotherapy

or just for the first five treatments, there have been no randomized trials that compare these approaches.

\section{Rescue therapy}

The role of antiemetics given on an as-needed basis has been investigated in three randomized trials [24, 30, 32].

In the latest study including 288 patients, the value of prophylactic versus rescue tropisetron was evaluated in fractionated radiotherapy of moderate or high emetogenic radiation fields [32]. Although no stratification in regard of radiation fields were conducted, it can be concluded that prophylactic tropisetron was superior over rescue tropisetron in regard to vomiting (risk 2.19 higher for rescue, $p=$ 0.001 ) and nausea (risk 1.89 higher for rescue, $p=0.009$ ). These results are in line with previous reported studies suggesting the benefit of $5-\mathrm{HT}_{3}$ receptor antagonists even as a rescue medication for RINV.

In another study, 455 patients who developed emesis and/or moderate/severe nausea after receiving fractionated radiotherapy to sites located between the thorax and pelvis were randomized to receive one of the following treatments: (1) two placebo orally disintegrating tablets (odt); (2) one 8-mg OND odt and one placebo odt (OND $8 \mathrm{mg}$ group) and (3) two $8 \mathrm{mg}$ OND odt (OND $16 \mathrm{mg}$ group) [24]. The study showed that OND was clinically superior to placebo independent of the OND dose prescribed. Both OND 8 and $16 \mathrm{mg}$ doses increased treatment success over the $12 \mathrm{~h}$ after treatment compared with placebo (53\% and $56 \%$, respectively, compared with $41 \%$ for placebo). Statistically significant differences were observed between OND $8 \mathrm{mg}$ and placebo $(p=0.026)$ and between OND $16 \mathrm{mg}$ and placebo $(p=0.008)$. There was no significant difference between the two doses of OND. This trial showed once again that a $5-\mathrm{HT}_{3}$ receptor antagonist, in this case ondansetron, given as a rescue treatment can control emesis and nausea effectively in radiotherapy patients who have already established symptoms [24].

The IGARR study by Maranzano et al. [28] conducted a double-blind randomized clinical trial in patients undergoing fractionated radiotherapy to the upper abdomen comparing prophylactic OND plus DEX versus placebo and, in case nausea and vomiting was observed, a crossover rescue treatment. Of the 400 patients planned as the sample size to reach in three consecutive years, only 155 patients entered the trial, of which 153 patients were evaluable. Comparing OND plus DEX prophylaxis with placebo, vomiting was observed in $30 \%$ versus $40 \%$ and nausea in $57 \%$ versus $67 \%$ of patients, respectively. The $10 \%$ of major control in the group treated with OND plus DEX was not statistically significant. In regard to the rescue treatment, the placebo given to the group of patients who developed vomiting in spite of the prophylaxis with OND plus DEX was effective in $24 \%$ of cases, whereas when vomiting was not controlled with placebo given as a prophylactic drug, the rescue with OND plus DEX was effective in $64 \%$ of cases. Thus, when a rescue treatment was used, OND plus DEX was significantly more effective than placebo in controlling vomiting (64\% versus $24 \%, p=$ 0.003 ). On the contrary, nausea was controlled in $56 \%$ of cases in both rescue treatment groups. In conclusion, this study showed that (a) in clinical practice, radiation oncologists generally underestimate the problem of nausea and vomiting in radiotherapy; and (b) antiemetic rescue treatment seems to be also effective [28].

In the observational study by Maranzano et al., it could be shown that antiemetic drugs were administered in $17 \%$ of the patients receiving radiotherapy, from which $12.4 \%$ were given prophylactically and $4.6 \%$ on a rescue basis [29].

Two open pilot studies evaluated the use of rescue treatment using a $5-\mathrm{HT}_{3}$ receptor antagonist in patients failing to achieve relief with non-5-HT-3-receptor-antagonist- 
antiemetics [31, 38]. In the first study, four patients who had RINV after prophylaxis with prochlorperazine and metoclopramide received rescue treatment with OND. All patients achieved complete protection from vomiting [38]. In the second trial, 34 patients experiencing RINV during fractionated radiotherapy to the abdomen were treated with tropisetron, which controlled vomiting in $73 \%$ of cases [31]. The beneficial role of $5-\mathrm{HT}_{3}$ receptor antagonists as rescue medication has been suggested in all these reports.

The role of rescue medication should be further explored in the low and minimal risk setting of RINV as the incidence of nausea and vomiting in the moderate and high emetogenic risk group is rather high, and a prophylactic use of antiemetics is mandatory in this setting.

\section{Evaluating an antiemetic strategy in RINV using a risk factor model}

In order to achieve an optimal treatment strategy to prevent nausea and/or vomiting, it could be useful to develop a riskadjusted treatment for RINV. Therefore, the individual risk of the patient to develop nausea and/or vomiting should be taken into consideration as well as the emetogenicity of the radiotherapeutic regimen and any simultaneous administration of chemotherapy [7, 9].

Patient factors are known to influence the risk of emesis in cancer patients. For example, previous chemotherapyinduced emesis is a significant prognostic factor for developing RINV (IGARR [16]). Individual well-known risk profiles according to patient-related emetogenic risk factors are age, gender, alcohol consumption, previous experience of nausea and vomiting and anxiety (Fig. 1) [7, 9, 17, 27]. The emetogenic potential of radiotherapy is divided into high, moderate, low and minimal in a similar fashion to the emetogenicity of chemotherapy. Although not prospectively proven, an approach taking the known risk factors into considerations to tailor a risk-adjusted antiemetic treatment for RINV might be advantageous for patients. With this strategy, it might be possible to further improve the protection rate in patients receiving RINV (Fig. 2).

\section{New recommendations and conclusions}

After the last MASCC Consensus Conference in 2004, new data on CINV and RINV suggested a need to update the existing guidelines. Therefore, MASCC convened an Expert Panel for a new International Antiemetic Consensus Conference which was held in Perugia, Italy, 20-22 June 2009. Data from the literature were evaluated, and relevant data with evidence of levels I and II were included. These provided the basis for the new proposed MASCC/ESMO guidelines discussed by the experts and described below.

According to the irradiated area (the most frequently studied risk factor); the guidelines are divided into four risk levels: high, moderate, low and minimal emetogenic risk of radiotherapy. The updated guidelines are shown in Table 3.

High risk Total body irradiation (TBI) is associated with a high risk of RINV. In patients receiving TBI, a prophylaxis with a $5-\mathrm{HT}_{3}$ receptor antagonist is recommended (MASCC level of confidence: high/level of consensus: high). The addition of dexamethasone to the 5-HT3 receptor antagonists has not been studied in this setting. However, if this approach adds efficacy, as occurs with chemotherapy, such regimen would be appropriate for patients submitted to TBI (MASCC level of confidence: low/level of consensus: high).
Fig. 1 Individual risk factors according to patient-related emetogenic risk factors $[6,7,9]$

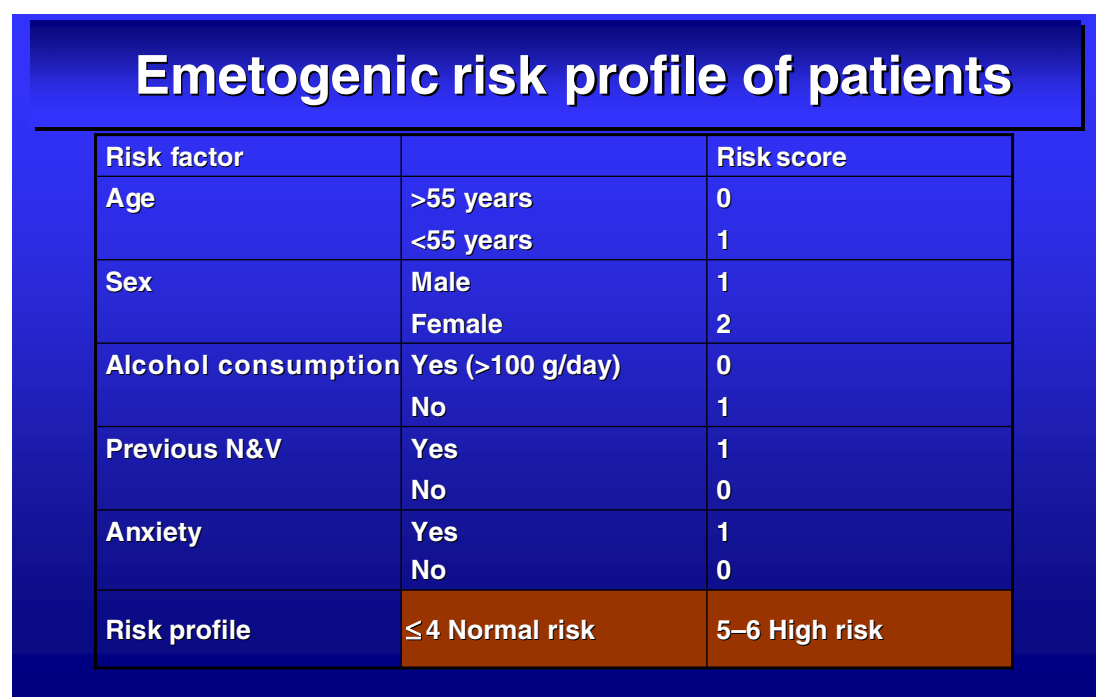


Fig. 2 Risk evaluation of emetogenic potential $[6,7,9]$

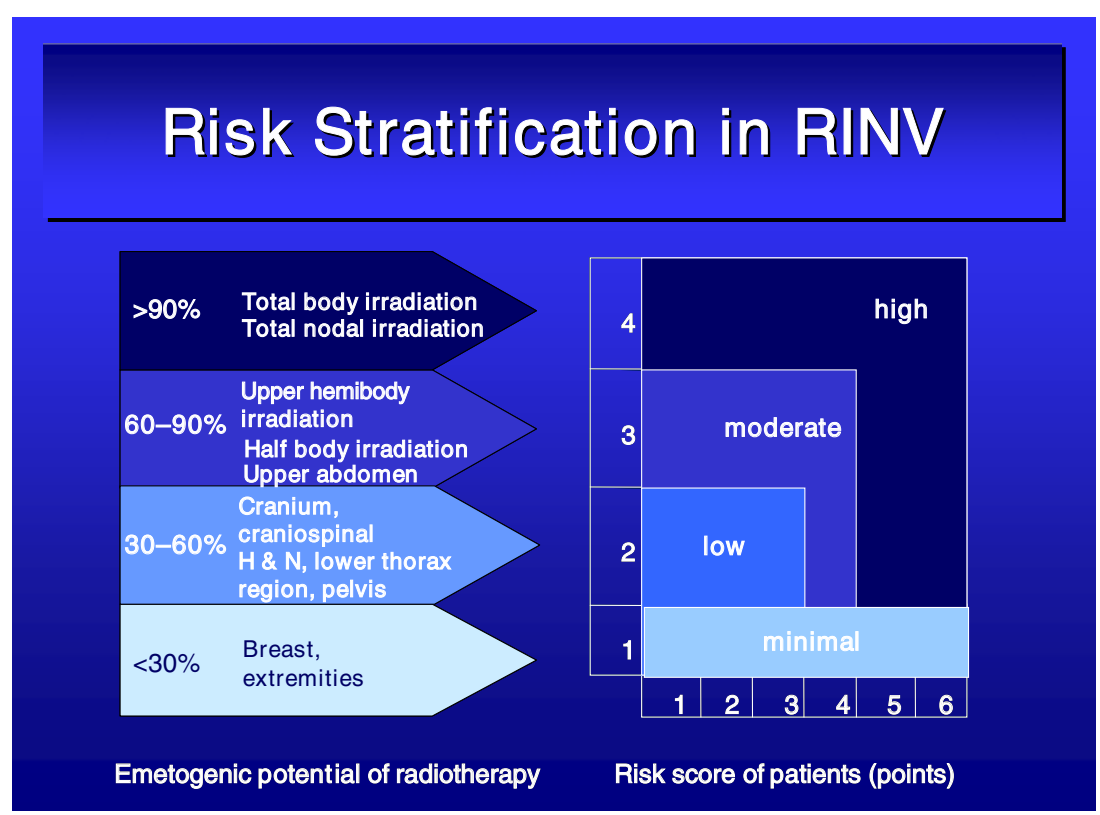

Moderate risk Radiation of the upper abdomen, half body irradiation (HBI) and upper body irradiation (UBI) is associated with a moderate risk of RINV. In patients receiving radiotherapy with moderate emetogenic risk, a prophylaxis with a $5-\mathrm{HT}_{3}$ receptor antagonist and optional in combination with a short course (day 1-5) of dexamethasone is recommended (MASCC level of confidence: high/ level of consensus: high for the 5- $\mathrm{HT}_{3}$ receptor antagonist, when combined with dexamethasone: MASCC level of confidence: moderate/level of consensus: high).

Low risk Radiation of the cranium (all), craniospinal radiation, $\mathrm{H} \& \mathrm{~N}$, lower thorax region and pelvis is associated with a low risk of RINV. In patients receiving radiotherapy with low emetogenic risk, a prophylaxis or a rescue therapy with a 5- $\mathrm{HT}_{3}$ receptor antagonist is recommended (for prophylaxis: MASCC level of confidence: moderate/level of consensus: high; for the $5-\mathrm{HT}_{3}$ receptor antagonist, for rescue: MASCC level of confidence: low/level of consensus: high).

Minimal risk Radiation of extremities and breast is associated with a minimal risk of RINV. In patients receiving radiotherapy with low emetogenic risk, a rescue with a dopamine receptor antagonist or prophylaxis with a $5-\mathrm{HT}_{3}$ receptor antagonist is recommended (MASCC level of confidence: low/level of consensus: high).

Concomitant chemotherapy In patients undergoing concomitant radiochemotherapy, the antiemetic prophylaxis should be according to the guidelines of chemotherapyinduced nausea and vomiting (CINV) choosing the emetogenic risk category of the used chemotherapeutic regimen.
However, in case the risk category of radiotherapy is higher than the concomitant applied chemotherapy, the risk category of radiotherapy has to be chosen to tailor the antiemetic treatment (MASCC level of confidence: low/ level of consensus: high).

The effect of RINV on patients' quality of life should not be underestimated, especially as such effects may compromise or delay treatments. Therefore, patients at risk of RINV should always be offered the most effective antiemetic prophylaxis as suggested by this updated MASCC/ESMO 2009 guidelines.

Furthermore, there is an additional need to investigate the importance of the individual risk factors of patients, the incidence of delayed nausea and vomiting, and the potential role of NK-1 receptor antagonists, the 5- $\mathrm{HT}_{3}$ receptor antagonists palonosetron and transdermal granisetron patch as well as the duration of antiemetic treatment.

\section{Note}

MASCC evidence Level of confidence (high-low) and grade of consensus (high-low) as used by the Multinational Association of Supportive Care are given in brackets.

ESMO evidence Levels of evidence (I-V) and grades of recommendation (A-D) as used by the American Society of Clinical Oncology are in given in brackets.

Conflict of interest statement The following authors either received research funding, honoraria, or have been a consultant to or an expert witness for: Feyer: GSK. Helsinn, Merck, Maranzano: No conflicts reported, Molassiotis: GSK, Merck, ProStrakan, Roila: GSK, Helsinn, Merck, Clark-Snow: No conflicts reported, Jordan: GSK, Helsinn, Merck. 


\section{References}

1. Aass N, Hatun DE, Thoresen M, Fossa SD (1997) Prophylactic use of tropisetron or metoclopramide during adjuvant abdominal radiotherapy of seminoma stage I: a randomised, open trial in 23 patients. Radiother Oncol 45:125-128

2. Belli C, Dahl T, Herrstedt J (2008) Palonosetron plus prednisolone in patients receiving fractionated radiotherapy plus weekly cisplatin. Support Care Cancer 16:01-004

3. Bey P, Wilkinson PM, Resbeut M, Bourdin S, Le Floch O, Hahne W et al (1996) A double-blind, placebo-controlled trial of I.V. dolasetron mesilate in the prevention of radiotherapy-induced nausea and vomiting in cancer patients. Support Care Cancer 4:378-383

4. Dimitrijevic J, Medic-Milijic N (2009) Prevention of nausea and vomiting induced by chemotherapy followed by combined chemo/ radiotherapy in head and neck cancer patients. Support Care Cancer 17:\# 02-009

5. Enblom A, Bergius Axelsson B, Steineck G, Hammar M, Borjeson S (2009) One third of patients with radiotherapyinduced nausea consider their antiemetic treatment insufficient. Support Care Cancer 17:23-32

6. Feyer P (2004) The importance of simple, easy-to-follow antiemetic guidelines. Acta Oncol 43 Suppl 15:5-8

7. Feyer P, Maranzano E, Molassiotis A, Clark-Snow RA, Roila F, Warr D et al (2005) Radiotherapy-induced nausea and vomiting (RINV): antiemetic guidelines. Support Care Cancer 13:122-128

8. Feyer P, Seegenschmiedt MH (2003) Antiemetic patterns of care for radiotherapy induced nausea and vomiting. ECCO 12:929

9. Feyer P, Seegenschmiedt MH, Steingraeber M (2005) Granisetron in the control of radiotherapy-induced nausea and vomiting: a comparison with other antiemetic therapies. Support Care Cancer 13:671-678

10. Feyer PC, Stewart AL, Titlbach OJ (1998) Aetiology and prevention of emesis induced by radiotherapy. Support Care Cancer 6:253-260

11. Feyer P, Zimmermann JS, Titlbach OJ, Buchali A, Hinkelbein M, Budach V (1998) Radiotherapy-induced emesis. An overview. Strahlenther Onkol 174 Suppl 3:56-61

12. Franzen L, Nyman J, Hagberg H, Jakobsson M, Sorbe B, Nyth AL et al (1996) A randomised placebo controlled study with ondansetron in patients undergoing fractionated radiotherapy. Ann Oncol 7:587-592

13. Goodin S, Cunningham R (2002) 5-Ht(3)-receptor antagonists for the treatment of nausea and vomiting: a reappraisal of their sideeffect profile. Oncologist 7:424-436

14. Horiot JC (2004) Prophylaxis versus treatment: is there a better way to manage radiotherapy-induced nausea and vomiting? Int $\mathbf{J}$ Radiat Oncol Biol Phys 60:1018-1025

15. Huang X, Guo N, Fan Y (1995) Ondansetron in the prophylaxis of acute emesis induced by supra-high single dose total body irradiation (TBI). Zhonghua Zhong Liu Za Zhi 17:64-66

16. Italian Group for Antiemetic Research (1992) Ondansetron+ dexamethasone vs metoclopramide+dexamethasone+diphenhydramine in prevention of cisplatin-induced emesis. Lancet 340:9699

17. Jordan K, Kinitz I, Voigt W, Behlendorf T, Wolf HH, Schmoll HJ (2009) Safety and efficacy of a triple antiemetic combination with the Nk-1 antagonist aprepitant in highly and moderately emetogenic multiple-day chemotherapy. Eur J Cancer 45:1184-1187

18. Jordan K, Schmoll HJ, Aapro MS (2007) Comparative activity of antiemetic drugs. Crit Rev Oncol Hematol 61:162-175

19. Khoo VS, Rainford K, Horwich A, Dearnaley DP (1997) The effect of antiemetics and reduced radiation fields on acute gastrointestinal morbidity of adjuvant radiotherapy in stage I seminoma of the testis: a randomized pilot study. Clin Oncol ( R Coll Radiol) 9:252-257
20. Kirkbride P, Bezjak A, Pater J, Zee B, Palmer MJ, Wong R et al (2000) Dexamethasone for the prophylaxis of radiation-induced emesis: a National Cancer Institute of Canada Clinical Trials Group Phase III Study. J Clin Oncol 18:1960-1966

21. Krengli M, Lazzari R, Manara M (1996) The use of granisetron per os in radiotherapy-induced emesis. Minerva Med 87:605-608

22. Kris MG, Hesketh PJ, Somerfield MR, Feyer P, Clark-Snow R, Koeller JM et al (2006) American Society of Clinical Oncology Guideline for Antiemetics in Oncology: Update 2006. J Clin Oncol 24:2932-2947

23. Lanciano R, Sherman DM, Michalski J, Preston AJ, Yocom K, Friedman C (2001) The efficacy and safety of once-daily kytril (granisetron hydrochloride) tablets in the prophylaxis of nausea and emesis following fractionated upper abdominal radiotherapy. Cancer Investig 19:763-772

24. Lebourgeois JP, Mckenna CJ, Coster B, Feyer P, Franzen L, Goedhals L et al (1999) Efficacy of an ondansetron orally disintegrating tablet: a novel oral formulation of this $5-\mathrm{Ht}(3)$ receptor antagonist in the treatment of fractionated radiotherapyinduced nausea and emesis. Emesis Study Group for the Ondansetron Orally Disintegrating Tablet in Radiotherapy Treatment. Clin Oncol (R Coll Radiol) 11:340-347

25. Lucraft HH, Palmer MK (1982) Randomised clinical trial of levonantradol and chlorpromazine in the prevention of radiotherapy-induced vomiting. Clin Radiol 33:621-622

26. Maisano R, Pergolizzi S, Settineri N (1998) Escalating dose of oral ondansetron in the prevention of radiation induced emesis. Anticancer Res 18:2011-2013

27. Maranzano E (2001) Radiation-induced emesis: a problem with many open questions. Tumori 87:213-218

28. Maranzano E, Bellavita R, De Angelis V (2004) Double-blind randomized clinical trial comparing prophylaxis vs. rescue treatment in patients undergoing fractionated upper abdomen radiotherapy. Radiother Oncol 73(Suppl 1):S388

29. Maranzano E, De Angelis V, Pergolizzi S, Constantini S, Lupattelli M, Frata P et al. (2009) Radiation-induced emesis (RIE): results of the Second Observational Multicenter Italian Trial. Radiother Oncol (in press)

30. Maranzano E, Feyer P, Molassiotis A, Rossi R, Clark-Snow RA, Olver I et al (2005) Evidence-based recommendations for the use of antiemetics in radiotherapy. Radiother Oncol 76:227-233

31. Miralbell R, Coucke P, Behrouz F, Blazek N, Melliger M, Philipp $S$ et al (1995) Nausea and vomiting in fractionated radiotherapy: a prospective on-demand trial of tropisetron rescue for nonresponders to metoclopramide. Eur J Cancer 31A:1461-1464

32. Mystakidou K, Katsouda E, Linou A, Parpa E, Kouloulias V, Nikolaou V et al (2006) Prophylactic tropisetron versus rescue tropisetron in fractionated radiotherapy to moderate or high emetogenic areas: a prospective randomized open label study in cancer patients. Med Oncol 23:251-262

33. NCCN (2009) National Comprehensive Cancer Network: Antiemesis, Clinical Practice Guidelines in Oncology-V.1.

34. Prentice HG, Cunningham S, Gandhi L, Cunningham J, Collis C, Hamon MD (1995) Granisetron in the prevention of irradiationinduced emesis. Bone Marrow Transplant 15:445-448

35. Priestman SG, Priestman TJ, Canney PA (1987) A double-blind randomised cross-over comparison of nabilone and metoclopramide in the control of radiation-induced nausea. Clin Radiol 38:543-544

36. Priestman TJ, Roberts JT, Lucraft H, Collis $\mathrm{CH}$, Adams M, Upadhyaya BK et al (1990) Results of a randomized, double-blind comparative study of ondansetron and metoclopramide in the prevention of nausea and vomiting following high-dose upper abdominal irradiation. Clin Oncol (R Coll Radiol) 2:71-75

37. Priestman TJ, Roberts JT, Upadhyaya BK (1993) A prospective randomized double-blind trial comparing ondansetron versus 
prochlorperazine for the prevention of nausea and vomiting in patients undergoing fractionated radiotherapy. Clin Oncol (R Coll Radiol) 5:358-363

38. Roberts JT (1992) Ondansetron in the control of refractory emesis following radiotherapy. Clin Oncol (R Coll Radiol) 4:67-68

39. Spitzer TR, Bryson JC, Cirenza E, Foelber R, Wallerstadt M, Stout C et al (1994) Randomized double-blind, placebo-controlled evaluation of oral ondansetron in the prevention of nausea and vomiting associated with fractionated total-body irradiation. J Clin Oncol 12:2432-2438

40. Spitzer TR, Friedman CJ, Bushnell W, Frankel SR, Raschko J (2000) Double-blind, randomized, parallel-group study on the efficacy and safety of oral granisetron and oral ondansetron in the prophylaxis of nausea and vomiting in patients receiving hyperfractionated total body irradiation. Bone Marrow Transplant 26:203-210

41. Sykes AJ, Kiltie AE, Stewart AL (1997) Ondansetron versus a chlorpromazine and dexamethasone combination for the prevention of nausea and vomiting: a prospective, randomised study to assess efficacy, cost effectiveness and quality of life following single-fraction radiotherapy. Support Care Cancer 5:500-503

42. The Italian Group for Antiemetic Research in Radiotherapy (1999) Radiation-induced emesis: a prospective observational multicenter Italian trial. Int J Radiat Oncol Biol Phys 44:619625

43. Tiley C, Powles R, Catalano J, Treleaven J, Eshelby J, Hewetson M et al (1992) Results of a double blind placebo controlled study of ondansetron as an antiemetic during total body irradiation in patients undergoing bone marrow transplantation. Leuk Lymphoma 7:317-321

44. Ungerleider JT, Andrysiak TA, Fairbanks LA, Tesler AS, Parker RG (1984) Tetrahydrocannabinol vs. prochlorperazine. The effects of two antiemetics on patients undergoing radiotherapy. Radiology 150:598-599

45. Urba S (2007) Radiation-induced nausea and vomiting. J Natl Compr Canc Netw 5:60-65

46. Wong RK, Paul N, Ding K, Whitehead M, Brundage M, Fyles A et al (2006) 5-Hydroxytryptamine-3 receptor antagonist with or without short-course dexamethasone in the prophylaxis of radiation induced emesis: a placebo-controlled randomized trial of the National Cancer Institute of Canada Clinical Trials Group (Sc19). J Clin Oncol 24:3458-3464

47. Yamamoto K, Nohara K, Furuya T, Yamatodani A (2005) Ondansetron, dexamethasone and an $\mathrm{Nk1}$ antagonist block radiation sickness in mice. Pharmacol Biochem Behav 82:24 29 